\title{
Immunoisolation of pancreatic B cells by microencapsulation
}

\author{
An in vitro study \\ S. Darquy and G. Reach \\ Unité de Recherches sur le Diabète et la Nutrition chez l'Enfant, INSERM, U 83, Faculté Villemin, Paris, France
}

\begin{abstract}
Summary. The selective permeability of alginate microcapsules, containing isolated rat islets of Langerhans or insulin secreting RINm5F cells, was investigated in vitro. An increase in insulin release was observed when microencapsulated islets were stimulated by glucose + theophylline, and when microencapsulated RINm5F cells were stimulated by arginine + theophylline. These findings demonstrate the permeability of the microcapsule membrane to these B-cell secretagogues and to insulin. Immunoisolation of RINm5F cells by microencapsulation was assessed using a ${ }^{51}$ chromium cytotoxicity test. Significant ${ }^{51} \mathrm{Cr}$ release was observed when nonencapsulated cells were incubated with complement and either the serum of a rabbit immunized with RIN cells or the se-
\end{abstract}

ra of two patients with recently diagnosed Type 1 (insulin-dependent) diabetes. This effect was not observed with encapsulated cells. Both free and encapsulated cells released $80 \%$ of their initial radioactivity when incubated in the presence of $\mathrm{HCl}$. These results clearly demonstrate pancreatic cell immunoisolation by microencapsulation. They also provide a method for the in vitro evaluation of the functional characteristics of microcapsules, in terms of both insulin permeability and immunoprotection.

Key words: Microencapsulation, RINm5F cells, complement fixing cytoxic antibodies, immunoprotection, bioartificial pancreas.
Microencapsulation of islets of Langerhans [1] has been proposed as a "bioartificial pancreas", whose function is to protect the graft by a membrane permeable to glucose and insulin but not to antibodies or lymphocytes [2]. Both in vitro [1, 3] and in vivo studies $[1,4]$ demonstrated that encapsulated islets (1) can be cultured for several weeks, (2) can secrete insulin in response to glucose with kinetics compatible with closed-loop insulin delivery, and (3) can correct hyperglycaemia in non syngeneic diabetic rats for several months.

Compared to other systems described so far, the microencapsulation technique devised by Lim and Sun for pancreatic islets has one great advantage as a potential bioartificial pancreas: unlike devices using cuprophantype artificial membranes, it allows microcapsule implantation without a vascular access [2]. However, with this technique, it is more difficult to define the molecular cut-off of the capsule membrane, which will control its selective permeability. The latter parameter is important, since the membrane is assumed to be permeable to glucose and insulin, but not to the factors responsible for immune rejection of the transplanted tissue. On the other hand, a protection against the cytotoxic activity of antibodies directed against pancreatic beta cells might also be required for islet transplantation in Type 1 (insulin-dependent) diabetic patients, since complement-fixing islet cell cytotoxic antibodies are spontaneously present in many of these patients $[5,6]$.

The aim of this work was therefore to determine whether microencapsulation is able to efficiently protect pancreatic B cells against cytotoxic antibodies; if confirmed, such immunoprotection would validate the concept of cell immunoisolation in a bioartificial pancreas. We used an in vitro approach in this study.

\section{Materials and methods}

\section{Pancreatic islets of Langerhans and RINm5F cells}

Pancreatic islets were isolated from adult Wistar rats by the collagenase method [7]. The RINm5F cell line, a gift of H.Oie, was maintained in monolayer culture in our laboratory for more than 1 year in RPMI 1640 medium (Gibco Laboratories, Grand Island, New York) supplemented with heat-inactivated $10 \%$ fetal calf serum, $2 \mathrm{mmol}$ L-glutamine, $100 \mathrm{U} / \mathrm{ml}$ penicillin and $100 \mu \mathrm{g} / \mathrm{ml}$ streptomycin.

\section{Microencapsulation procedure}

Islets or RINm5F cells were encapsulated as described by Goosen et al. [8] with slight modifications. Briefly, islets of Langerhans were en- 


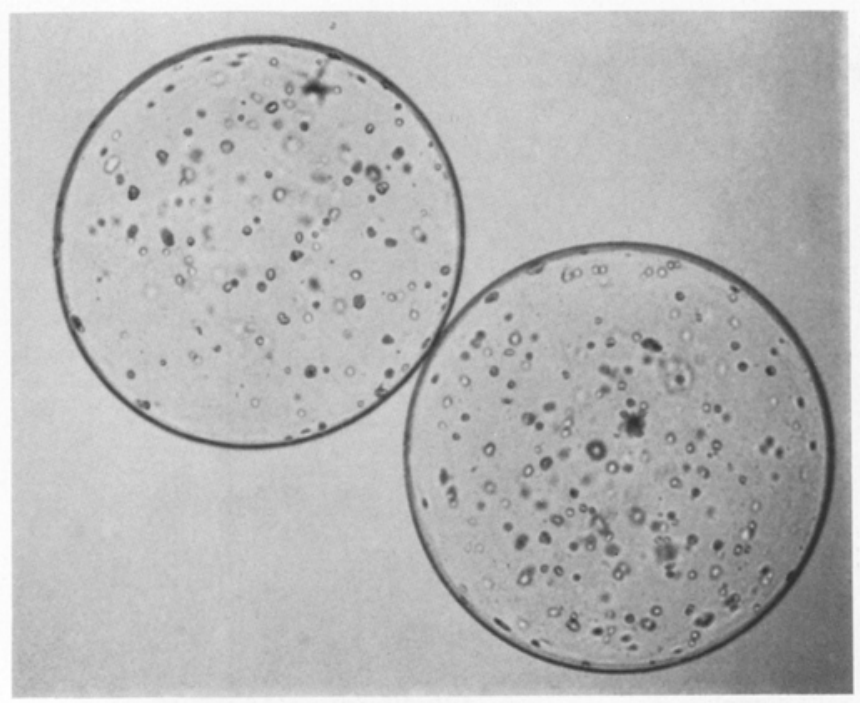

Fig. 1. Microencapsulated RINm5F cells $24 \mathrm{~h}$ after preparation. Note the absence of any cell grown outside the capsule

capsulated immediately after isolation. RINm $5 \mathrm{~F}$ cells were detached from culture flasks by incubation for $10 \mathrm{~min}$ at $37^{\circ} \mathrm{C}$ with calcium and magnesium free Hank's balanced salt solution (Flow Laboratory, Rockville, Maryland). Four hundred islets, or $4 \times 10^{6}$ RIN cells were suspended in $5 \mathrm{ml}$ of an $1.5 \%$ sodium alginate solution (Kelco, Merck, Rahway, New Jersey). Alginate droplets containing the islets or cells were formed by syringe pump extrusion under an air jet, and collected for $5 \mathrm{~min}$ in $1.1 \%$ calcium chloride solution to form calcium alginate gel to entrap the cells. The calcium alginate beads were successively coated by washing with L-polylysine (MW 50000, Sigma, St. Louis, Missouri), dissolved at a $5 \mathrm{mg} / 10 \mathrm{ml}$ concentration in 2-(N-cyclohexylamino) ethan-sulfuric acid (CHES) buffer (Sigma), for $6 \mathrm{~min}$ and with sodium alginate $0.075 \%$ for $4 \mathrm{~min}$. The alginate gel inside the microcapsule was liquefied by washing with $0.025 \mathrm{~mol}$ sodium citrate, $\mathrm{pH} 7.4$ for $16 \mathrm{~min}$, and with $0.05 \mathrm{~mol}$ sodium citrate for $6 \mathrm{~min}$. Microcapsules containing islets and RIN cells were washed three times with physiological saline. The islets were transferred into Minimal Eagle Medium (MEM medium, Gibco, Paisley, Scotland), containing 10\% fetal calf serum, $2 \mathrm{mmol}$ glutamine, $1 \mathrm{mmol}$ sodium pyruvate, $0.814 \mathrm{mg} / 1$ non essential aminoacids and antibiotics, and the cells, into RPMI 1640 culture medium. Fig. 1 represents microcapsules (mean size $=500 \mu \mathrm{m}$ diameter) containing RINm5F cells, $24 \mathrm{~h}$ after encapsulation, demonstrating that all the cells were inside the microcapsules.

\section{Assessment of glucose, arginine, and insulin permeability}

Stimulation of free and encapsulated islets. After $18 \mathrm{~h}$ of culture at $37{ }^{\circ} \mathrm{C}$ in $6 \% \mathrm{CO}_{2}$, free or encapsulated islets were incubated in wells of microtest plates (10 islets/well), and washed four times with $250 \mu 1$ basal medium (MEM medium, containing $5.5 \mathrm{mmol}$ glucose). During each washing, free and encapsulated islets were left in the medium for $10 \mathrm{~min}$ to remove insulin which might have built up during the previous culture period. After completion of the washing, free and encapsulated islets were incubated for $30 \mathrm{~min}$ in the basal medium and the supernatant was then collected for determination of basal insulin secretion. Both free and encapsulated islets were subsequently washed four times with stimulatory medium, (MEM medium containing $16.5 \mathrm{mmol}$ glucose $+5.5 \mathrm{mmol}$ theophylline); after $30 \mathrm{~min}$ incubation in this medium, the supernatant was collected for determination of stimulated insulin secretion.

Stimulation of free and encapsulated RIN cells. The procedure used was similar to that described above except that: (1) Encapsulated cells were stimulated after 10 days of culture in RPMI 1640 medium. (2) Arginine was used as a secretagogue, since RINm5F cells do not respond to glucose [9]. The stimulatory medium was therefore MEM Eagle medium containing $20 \mathrm{mmol}$ arginine $+5.5 \mathrm{mmol}$ theophylline, and (3) incubation periods in basal and stimulatory medium each lasted for $1 \mathrm{~h}$. In this experimental design, the same batches of free or encapsulated islets or RINm5F cells were therefore sequentially incubated in basal and stimulatory medium to assess the response to the secretagogues. This was important in the case of encapsulated RINm5F cells since the number of cells might vary from one capsule to the other.

Insulin determination. Samples were stored at $-20^{\circ} \mathrm{C}$ until insulin determination. The insulin concentration was assayed by the radio-immunological method using rat insulin as standard and double antibody separation [10].

\section{In vitro assessment of immunoprotection}

These experiments were performed on encapsulated RINm5F cells cultured for 2 to 4 days, and free cells were used as control. Immunoprotection of microencapsulated RINm5F cells was assessed by an assay for release of ${ }^{51} \mathrm{Cr}$, modified from Sai [6]. Free cells were resuspended in RPMI 1640 medium, to a cell density of $2 \times 10^{6}$ cells $/ \mathrm{ml}$, and $500 \mathrm{ul}$ of the cell suspension was incubated at $37^{\circ} \mathrm{C}$ under $6 \%$ $\mathrm{CO}_{2}$ for $1 \mathrm{~h}$ with $100 \mu{ }^{51} \mathrm{Cr}$ sodium chromate (Amersham France, $1 \mathrm{mCi} / \mathrm{ml}$ ). Encapsulated RIN cells were allowed to sediment, and the supernatant was discarded. The pellet, i. e. about $1 \mathrm{ml}$ of capsules containing cells, was incubated for $2 \mathrm{~h}$ with $200 \mu \mathrm{l}$ of the sodium chromate solution. Incubation was followed by 4 washing steps, as described above, to eliminate free ${ }^{51} \mathrm{Cr}$. It was verified that chromium uptake by empty capsules was negligible compared to that obtained with capsules containing cells $(264 \pm 98 \mathrm{cpm}, n=6$, vs 3289 $\pm 193 \mathrm{cpm}, n=5$, the latter comprising five different preparations of capsules seeded with RINm5F cells). Aliquots of labelled free or encapsulated cells were placed in $5 \mathrm{ml}$ plastic test tubes $\left(5 \times 10^{3}\right.$ cells in $100 \mu \mathrm{l}$ medium, or $100 \mu \mathrm{l}$ of capsules/tube), and incubated for $1 \mathrm{~h}$ at $37^{\circ} \mathrm{C}$ under $6 \% \mathrm{CO}_{2}$. Twenty $\mu \mathrm{l}$ of control or immune sera (see below) were then added to each tube. After incubation for $45 \mathrm{~min}$ in a thermostated waterbath under slow shaking, $(1$ shake $/ \mathrm{s}), 80 \mu \mathrm{l}$ of guinea pig complement (diluted three times with culture medium) (Cederlane, Eurobio Paris, France) were added to each tube, and the tubes were incubated for the next hour. The final volume in each tube was thus $200 \mathrm{ul}$. The tubes were subsequently centrifuged for $10 \mathrm{~min}$ at $1000 \mathrm{rev} / \mathrm{min}$, and radioactivity was determined with a gamma counter (Kontron-Intertechnics, Basel, Switzerland) both in the $100 \mathrm{ul}$ of supernatant and in the $100 \mu \mathrm{l}$ pellet remaining in the tube. Maximum chromium release was determined by incubating the free or encapsulated cells with $100 \mu \mathrm{l}$ of distilled water acidified with $\mathrm{HCl}$ to $\mathrm{pH} 2$. For determination of non-specific chromium release, RPMI 1640 medium was used instead of serum and complement; the effect of complement alone was also determined by replacing the serum with $20 \mu \mathrm{l}$ RPMI 1640 medium during the 45 min incubation; lastly, the effect of heat inactivation of the complement $\left(40 \mathrm{~min}\right.$ heating at $\left.56^{\circ} \mathrm{C}\right)$ was assessed.

Control and immune sera consisted of (1) the serum of a normal rabbit (Fauve de Bourgogne, Lessieu, Bray-Lu, France); (2) the serum of the same rabbit after immunization with RINm5F cells, obtained by three subcutaneous injections of $10^{6}$ cells in $500 \mu$ l culture medium with $500 \mu \mathrm{l}$ of Freund's adjuvant (one injection every 2 weeks); (3) the sera of six control human subjects and (4) the sera of two recently diagnosed Type 1 (insulin-dependent) diabetic patients. All sera were complement inactivated by heating for $40 \mathrm{~min}$ at $56^{\circ} \mathrm{C}$.

Expression of results. The sum of the radioactivities present in the supernatant and the pellet yielded the initial total radioactivity. This was of particular interest in the case of capsules, in which the amount of radioactivity might have varied from one tube to the other. With this 


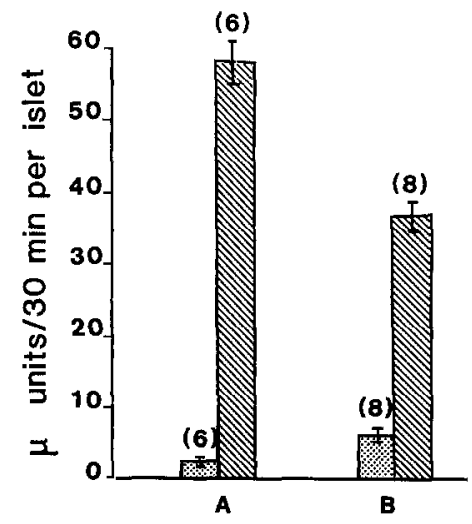

Fig. 2. Insulin release by free islets (A) and microencapsulated islets (B) after $30 \mathrm{~min}$ incubation in basal medium (dotted columns) or stimulatory medium (hatched columns). Number of separate experiments are given in parentheses

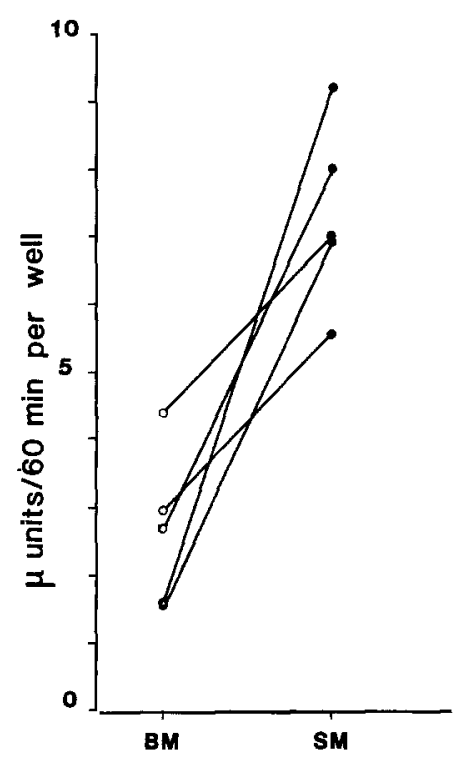

Fig.3. Insulin release in five separate experiments, by encapsulated RINm5F cells, after 60 min in basal medium (open circles) or in stimulatory medium (closed circles). Each point represents the mean of at least 4 incubation wells

procedure, however, it was possible to determine exactly, for each tube, the percentage of initial radioactivity released under the different incubation conditions by using the formula:

${ }^{51} \mathrm{Cr}$ Release $(\%)=\frac{\begin{array}{l}\text { in } 100 \mu \text { lioactivity } \\ \text { radioactivity }+\quad \text { radioactivity } \\ \text { in } 100 \mu l \text { supernatant } \quad \text { in } 100 \mu l \text { pellet }\end{array}}{\text { A }} \times 100$

A cytotoxic index was also calculated, taking into account, for each experiment, the maximal ${ }^{51} \mathrm{Cr}$ release (in the presence of $\mathrm{HCl}$ ) and the nonspecific ${ }^{51} \mathrm{Cr}$ release (after incubation with RPMI culture medi$u m$ ), according to the following formula:

\begin{tabular}{|c|c|c|}
\hline $\begin{array}{c}{ }^{51} \mathrm{Cr} \text { Release with } \\
\text { serum tested }\end{array}$ & $\begin{array}{c}{ }^{51} \mathrm{Cr} \text { Release with } \\
\text { RPMI }\end{array}$ & \\
\hline $\begin{array}{l}{ }^{51} \mathrm{Cr} \text { Release with } \\
\mathrm{HCl}\end{array}$ & $\begin{array}{c}{ }^{51} \mathrm{Cr} \text { Release with } \\
\text { RPMI }\end{array}$ & \\
\hline
\end{tabular}

Statistics. In each experiment, each set of incubation was tested at least in quadruplicate, allowing to calculate mean values; these values
Table 1. ${ }^{51}$ Chromium release from free or encapsulated RINm5F cells, under different incubation conditions

\begin{tabular}{|c|c|c|}
\hline & Free cells & $\begin{array}{l}\text { Microencapsulated } \\
\text { cells }\end{array}$ \\
\hline $\mathrm{HCl}$ & $91 \pm 2(13)$ & $76 \pm 3(11)$ \\
\hline RPMI & $13 \pm 2(13)$ & $15 \pm 3(11)$ \\
\hline Complement & $11 \pm 1(7)$ & $22 \pm 3(7)$ \\
\hline Normal rabbit + complement & $11 \pm 2(6)$ & $22 \pm 3 \quad(6)$ \\
\hline \multicolumn{3}{|c|}{ Control human subjects } \\
\hline $\begin{array}{l}\text { + heat inactivated } \\
\text { complement }\end{array}$ & $8 \pm 1(6)$ & $9 \pm 2 \quad(3)$ \\
\hline + complement & $9 \pm 1(6)$ & $13 \pm 4$ \\
\hline \multicolumn{3}{|l|}{ Immune rabbit } \\
\hline $\begin{array}{c}\text { + heat inactivated } \\
\text { complement }\end{array}$ & $10 \pm 1$ & $27 \pm 3$ \\
\hline+ complement & $57 \pm 8(8)$ & $18 \pm 2 \quad(6)$ \\
\hline \multicolumn{3}{|l|}{ Type 1 patient A } \\
\hline $\begin{array}{l}\text { + heat inactivated } \\
\text { complement }\end{array}$ & $20 \pm 6(6)$ & $17 \pm 5 \quad(6)$ \\
\hline + complement & $57 \pm 10 \quad(6)$ & $15 \pm 6 \quad(6)$ \\
\hline \multicolumn{3}{|l|}{ Type 1 patient $B$} \\
\hline $\begin{array}{l}\text { + heat inactivated } \\
\text { complement }\end{array}$ & $15 \pm 4(6)$ & $16 \pm 6 \quad(6)$ \\
\hline+ complement & $47 \pm 11$ & $15 \pm 6 \quad(6)$ \\
\hline
\end{tabular}

Results are expressed as the percentage of initial radioactivity released after $1 \mathrm{~h} 45 \mathrm{~min}$ incubation, as mean \pm SEM, with number of separate experiments in parentheses

were used to calculate final data which are given as mean \pm SEM of different experiments (namely different capsule preparations), whose number is given between parentheses. Statistical significance was evaluated by paired, two-tailed Student's t-test [11].

\section{Results}

Permeability to glucose, arginine, theophylline and insulin

Insulin secretion by free and encapsulated islets of Langerhans in response to glucose theophylline. Both free and encapsulated islets responded to incubation in the stimulatory glucose + theophylline medium by significantly increasing their insulin release ( $p<0.001$, Fig. 2$)$, although the magnitude of the response seemed to be larger in case of free islets.

Insulin secretion by encapsulated RINm5F cells in response to arginine theophylline. Although the magnitude of the response varied from one experiment to the other, stimulation of RIN cells by arginine + theophylline consistently induced an increase in insulin secretion in all of five consecutive experiments $(p<0.01$, Fig. 3).

\section{Immunoprotection}

${ }^{51}$ Chromium cytotoxicity test on free and microencapsulated RINm $5 F$ cells. In both free and microencapsulated cells, incubation with acidified distilled water elicited the release of more than $75 \%$ of the initial total radioactivity (Table 1). By contrast, when preparations were in- 
cubated with culture medium, or with guinea pig complement, or with complement plus the serum of a normal rabbit, or with complement plus the sera of six control human subjects, chromium release remained at less than $15 \%$ in the case of free cells, and less than $25 \%$ in the case of microencapsulated cells. These findings demonstrated that the cytotoxic activity of immune sera could be compared in free and microencapsulated cells, i.e. that the protection afforded by the capsule membrane could be assessed in vitro.

Incubation of free cells with the sera of the immunized rabbit or of two Type 1 (insulin-dependent) diabetic patients in the presence of complement produced $a^{51} \mathrm{Cr}$ release of more than $45 \%$. This effect was not observed when the complement had been inactivated by heating at $56^{\circ} \mathrm{C}$. By contrast, chromium release by encapsulated cells remained below $20 \%$, even after incubation with native complement. These results were not significantly different from those observed during the control incubations.

A cytotoxic index was calculated which took into account the maximal and non-specific chromium release in each individual experiment. Figure 4 gives the index obtained with the sera of the control human subjects and of the two diabetic patients. In free cells, it was about $50 \%$ when they were incubated with immune sera and native complement. However, in encapsulated cells incubated under the same conditions, this index never exceeded $10 \%$.

\section{Discussion}

The development of bioartificial pancreas systems, separating pancreatic cells from the host by an artificial membrane, should permit non syngeneic transplantation for the cure of human diabetes mellitus without immunosuppression [2]. However, effective cell immunoprotection is essential for two reasons: First, it is necessary to protect the graft against the humoral and cellular factors responsible for its immune rejection; second, in the specific case of diabetes mellitus, complement fixing antibodies, whose cytotoxic activity against pancreatic cells has been demonstrated in vitro, are spontaneously present in many Type 1 (insulin-dependent) diabetic patients $[5,6]$. Therefore, the concept of a bioartificial pancreas assumes that the membrane is not permeable to antibodies and complement. For instance, in experiments using "diffusion chambers", it was possible to avoid graft rejection by protecting the transplanted tissue with a membrane fully permeable to antibodies, provided that cellular contact with the host tissue was prevented [12]; however, such protection was not observed in experimental models with preformed antibodies [13]. So far, assessment of long-term immunoprotection by different kinds of bioartificial pancreas, namely diffusion chambers, hollow fibers, microcapsules [2], was only investigated in drug-induced models

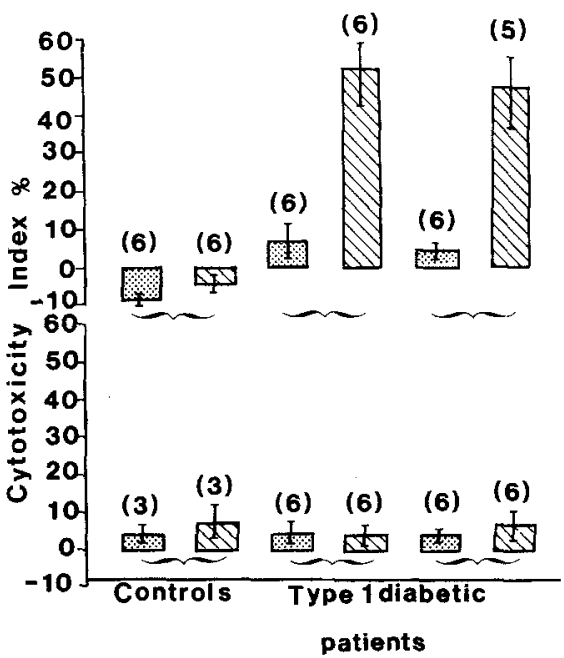

Fig.4. Cytotoxicity index determined on free RINm5F cells (upper part), and on microencapsulated RINm5F cells (lower part), after incubation with sera from control human subjects, or two Type 1 (insulin-dependent) diabetic patients, in the presence of heat-inactivated (dotted columns) or native complement (hatched columns)

of diabetes, in which the presence of an immune response against the pancreas has not been documented. Consequently, these experimental conditions were not suitable for demonstrating the efficiency of immunoprotection by the membrane.

Our data demonstrate clearly that microcapsules, which are permeable to glucose, arginine, theophylline and insulin, are nevertheless able to efficiently protect the pancreatic $B$ cell against the cytotoxic factors present in the serum of a rabbit immunized with pancreatic cells or in the sera of Type 1 (insulin-dependent) diabetic patients. This demonstration validates the concept of cell immunoprotection in a bioartificial pancreas.

To evaluate the protection against cytotoxic antibodies, we set up a cytotoxic test based on ${ }^{51}$ chromium uptake and release in encapsulated cells. The difficulty was to determine the initial radioactivity taken up by these cells, which varied from one capsule to the other, since the number of cells per capsule is different; this obstacle was overcome by performing the assay in test tubes, which proved a simple accurate method of determining initial radioactivity by double counting of both the supernatant and pellet after centrifugation following incubation. This method could be used for other purposes.

It can be observed that encapsulated RINm5F cells released apparently less ${ }^{51}$ chromium when incubated in the presence of $\mathrm{HCl}$. This might be due to an incomplete diffusion of ${ }^{51} \mathrm{Cr}$ across the membrane, which would in turn decrease the calculated percentage of ${ }^{51} \mathrm{Cr}$ release. We therefore calculated a cytotoxicity index taking into account, in each experiment, both the maximal $(\mathrm{HCl})$, and minimal, non specific (RPMI incubation), chromium release (Fig. 4). 
In conclusion, the present results do not demonstrate that these kinds of microcapsules allow for longterm islet survival in allogeneic graft transplantation, since other problems are also involved such as the longterm biocompatibility of the membranous material against the host or against the graft. In vivo experiments using the animal models closest to man are required to deal with these questions. However, this study does provide a method for in vitro evaluation of the selective permeability to insulin and anti-islet complement fixing-antibodies of a specific capsule preparation. The method could therefore be recommended for testing microencapsulated islet preparations before transplantation, in order to establish that the graft is effectively protected by the microcapsules against the cytotoxic activity of the serum of the patient himself.

Acknowledgements. We wish to express our gratitude to Dr. AM. Sun for showing us the microencapsulation technique. This work was supported in part by an MRI grant (no. 82MI224) and by a grant from l'Aide aux Jeunes Diabetiques. Thanks are due to Mme Dreyfus for editorial assistance.

\section{References}

1. Lim F, Sun A (1980) Microencapsulated islets as bioartificial endocrine pancreas. Science 210: 908-910

2. Reach G (1984) Bioartificial pancreas. Present state and future prospects. Biomed Biochim Acta 43: 569-576

3. Leung YF, O'Shea GM, Goosen MFA, Sun AM (1983) Microencapsulation of crystalline insulin or islets of Langerhans: an insulin diffusion study. Artif Organs 7: 208-212

4. Sun AM, O'Shea G, Goosen M (1983) Injectable, biocompatible, islet microcapsules as bioartificial pancreas. Artif Organs 7:81
5. Dobersen MJ, Shorff JE, Ginsberg-Fellner F, Notkins A (1980) Cytotoxic autoantibodies to beta cells in the serum of patients with insulin dependent diabetes mellitus. N Engl J Med 303: 1493-1498

6. Sai P, Boitard C, Debray-Sachs M, Pouplard A, Assan R, Hamburger J (1981) Complement fixing islet-cell antibodies from some diabetic patients alter insulin release in vitro. Diabetes 30: 1051-1057

7. Lacy P, Kostianovsky M (1967) Method for the isolation of intact islets of Langerhans from rat pancreas. Diabetes 16: 35-38

8. Goosen M, O'Shea G, Gharapetian HM, Chou S, Sun AM (1985) Optimization of microencapsulation parameters: semipermeable microcapsules as a bioartificial pancreas. Biotechnol Bioeng 27: $146-150$

9. Praz GA, Halban PA, Wolheim CB, Blondel B, Strauss AJ, Renold AE (1983) Regulation of immunoreactive-insulin release from a rat cell line (RINm5F). Biochem J 210: 345-355

10. Morgan CR, Lazarow A (1963) Immunoassay of insulin: two antibody system: plasma insulin levels of normal, subdiabetic and diabetic rats. Diabetes 12: 115-126

11. Sokal R, Rohlf F (1969) Biometry. San Francisco, Freeman

12. Algire GH, Weaver JM, Prehn RT (1954) Growth of cells in vivo in diffusion chambers. I. Survival of homografts in immunized mice. J Natl Cancer Inst 15: 493-501

13. Weaver JM, Algire GH, Prehn RT (1955) The growth of cells in vivo in diffusion chambers. II. The role of cells in the destruction of homografts in mice. J Natl Cancer Inst 15: 1737-1757

Received: 29 May 1985

and in revised form: 27 June 1985

Dr. G. Reach M.D.,

CHU Villemin, INSERM U 83

10 Avenue de Verdun

F-75010 Paris

France 